\title{
透析患者におけるリドカインテープの適正な貼付方法の探索に関する研究
}

\author{
大井一弥
}

\section{Differences of Pain Anesthetic Effect Expression on Using Lidocaine Tape in Hemodialysis Patients}

\author{
Kazuya OoI \\ Department of Pharmacotherapy, Josai University, 1-1 Keyakidai, Sakado City 350-0295, Japan
}

(Received July 2, 2007)

\begin{abstract}
There are many clinical problems which are raised but not responded sufficiently, and pharmacy school plays a key role to solve these problems. We introduce the case in which pharmacy school collaborated with hospital about the clinical problem. Many hemodialysis patients experience much physical and mental pain associated with needle insertion before dialysis. To alleviate this, tape-type lidocaine-containing local anesthetic patches (Penles ${ }^{\circledR}$, Wyeth, Japan) are widely used. However, the efficacy of Penles ${ }^{\circledR}$ in alleviating pain associated with needle insertion is often limited. Hemodialysis patients exhibit a variety of dermatological symptoms, such as pruritus, xerosis, and erythema. These symptoms may affect the transdermal lidocaine absorption. We surveyed the current use of Penles ${ }^{\circledR}$ and evaluated skin conditions in hemodialysis patients. The results revealed that hemodialysis patients had applied Penles ${ }^{\circledR}$ for about 100 minutes, and the electrical capacitance of the skin surface of hemodialysis patients was significantly lower than that of healthy volunteers. In consideration of these results, we investigated a skin hydration method to enhance the absorption of lidocaine with porcine ear skin. In the result, lidocaine concentration increased significantly with skin hydration. Furthermore, this method was examined with hemodialysis patients, and the results revealed that this skin hydration method might be beneficial. This case was carried out by the collaboration between hospital and pharmacy school, and a clinical sense is necessary for such pharmaceutical research.
\end{abstract}

Key words_ — pharmaceutical clinical research; clinical sense; collaboration; lidocaine tape; hemodialysis patient

\section{1. はじめに}

医療現場では，臨床的な問題提起がなされるもの

の，かならずしも満足な対応ができないことが数多 くある．医療現場で解決できず，また製薬会社も情 報を持ち合わせていないような場合，臨床センスを 持ち合わせた薬学部教員の存在が重要となってく る. 今回，医療現場との共同体制によって透析患者 におけるリドカインテープ剂の効果的な使用法を提 案することができた事例を紹介する.

現在，わが国において透析療法を実施している患 者数は約 26 万人であり，そのうち約 25 万人が血液 透析を導入している。血液透析導入患者は，それら を施行するたびにシャント部位へ穿刺を施さなけれ ばならないが，それによる疼痛は患者に肉体的，精

城西大学薬学部（干350-0295 坂戸市けやき台 1-1）

e-mail: zooi@ josai.ac.jp

本総説は, 日本薬学会第 127 年会シンポジウム S47 で 発表したものを中心に記述したものである.
神的に大きな苦痛を与える，また，患者が訴える疼 痛は，医療行為を行う者に対してもスムーズな穿刺 を妨げる要因となる。そこで, 穿刺時の疼痛を緩和 するために局所麻酔薬であるリドカインを含有する ペンレス ${ }^{\circledR}$ (ワイス侏）が 1994 年に発売され，現在 臨床の場で広く用いられている．添付文書上には， ペンレス ${ }^{\circledR}$ は「穿刺予定部位に約 30 分間貼付する」 と記載されている。しかし，患者及び医療スタッフ からは 30 分間の貼付では効果が不十分であると経 験上いわれており，長時間の貼付が一般的となって いる，つまり，添付文書上の用法と臨床の現場での 使用に差異が生じている現状にある。一方で，ペン レス ${ }^{\circledR}$ 長時間の貼付により発赤や掻痒などの症状 が増加する可能性も考えられている. ${ }^{1)}$

そこで，本研究では，透析患者に適したペンレ ス $の$ 貼付条件を導くことを目的とし，透析患者の ペンレス ${ }^{\circledR}$ 使用実態調査, ペンレス ${ }^{\circledR}$ の効果発現に対 し影響を及ぼす因子の探索，さらに動物実験による 
基礎的検討を基に，水分処置法の臨床応用を行つた.

\section{2. 透析患者におけるペンレス ${ }^{\circledR}$ 使用実態}

今回行った使用実態調查では，医療スタッフから 30 分間以上貼付の指示を受けていた患者は約 $80 \%$ であった．このことは，添付文書では，30 分の貼 付を指示しているにも係わらず，情報を伝える側の 認識としても 30 分では効果が期待できないことを 示唆している。 さらに，実際に添付文書通りに貼付 している患者は 4\%に過ぎず，残りは 60-120 分間 貼付しており，平均貼付時間は約 100 分であった。 医療スタッフの用法指示や貼付の現状から添付文書 上の用法と大きな違いがみられ，長時間の貼付が一 般的になっていることが明らかとなった。

\section{3. 透析患者の皮膚状態}

透析患者は，乾燥や掻痒などの特徵的な皮膚症状 を有していることが知られている. ${ }^{2-4)}$ ペンレス ${ }^{\circledR}$ 効果発現に対し影響を及ぼす因子として，われわれ はこの透析患者の皮膚特性に着目し，TEWL（経 表皮水分損失)，皮膚 $\mathrm{pH}$, capacitance (角質水分量) の測定を行った。その結果，TEWL 及び skin pH は対照群と透析患者群間に有意な差はなかったが, capacitance は透析患者において有意に減少してい た．薬物の経皮吸収において，角質水分量は重要な

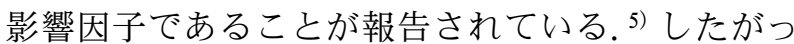
て，角質水分量を増加させることでペンレス ${ }^{\circledR} に$ 含 まれるリドカインの経皮吸収を高めることができる のではないかと考えられた。

\section{4. ペンレス ${ }^{\circledR}$ 最適な貼付条件に関する基礎的} 検討

ヒトの皮膚の性質に近い豚耳皮膚を用い，角質水 分量を増加させた状態でペンレス ${ }^{\circledR}$ 貼付した際の 皮膚中リドカイン量について検討した。角質水分量 を増加させる方法として, 約 $37^{\circ} \mathrm{C}$ に温めた精製水 を染み込ませた脱脂綿を豚耳皮膚に 5 分間適用する 方法を用いた。

水分処置前の豚耳皮膚の capacitance は, $40.52 \pm$ $8.01 \mathrm{AU}$ であり，5 分間の水分処置により $83.32 \pm$ $13.07 \mathrm{AU}$ と上昇した。 さらに，ペンレス ${ }^{\circledR}$ 貼付後 の豚耳皮膚中のリドカイン量を HPLCにて測定 し，非処置群と分処置群で比較したところ，30 分 貼付時は水分処置群では非処置群の約 2.5 倍， 120 分貼付時は約 1.5 倍に増加した（Fig. 1)。また，非 処置群の 120 分㙋付時と水分処置群の 30 分貼付時

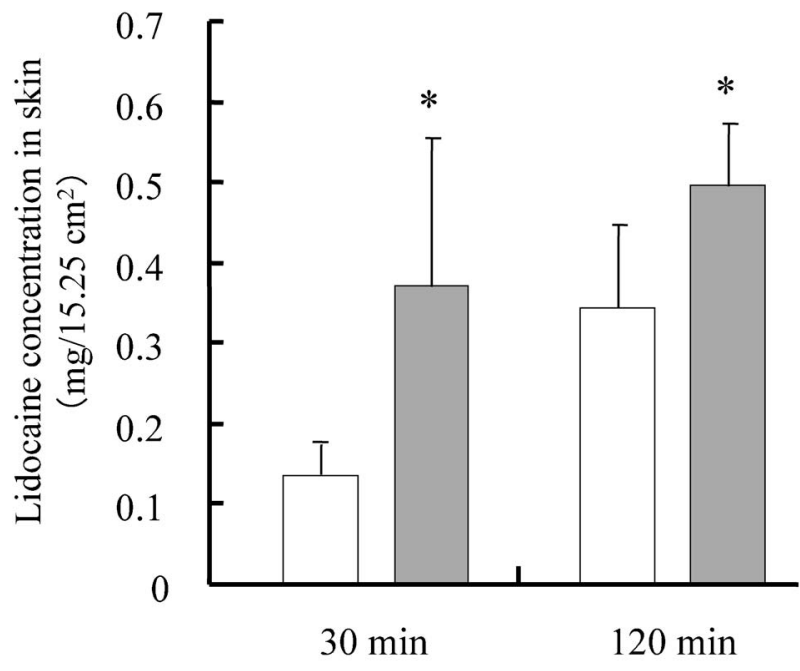

Application time of Penles ${ }^{\circledR}$

Fig. 1. Influence of Skin Hydration on Lidocaine Concentration in Porcine Ear Skin in Each Application Time of Lidocaine Tape

Open and filled bars represent the lidocaine concentration with no treatment and skin hydration, respectively. Each bar is a mean \pm S.D. $(n=5)$. *Significant $(p<0.05)$ when compared to no treatment in each application time.

を比較した場合，皮膚中リドカイン量はほぼ同等で あった。さらに，これまでの検討から得られたペン レス ${ }^{\circledR}$ 貼付前の capacitance と皮膚中リドカイン量 をプロットしたところ，両者の間には良好な相関が 認められた。以上の結果により，ペンレス ${ }^{\circledR}$ 長時 間貼付している透析患者においても，水分処置によ り貼付時間を短縮できる可能性が示唆された。

\section{5. 水分処置法の臨床応用}

基礎的検討で明らかになった有効性が臨床でも同 様の傾向を示すか否かについて，透析患者 20 名に おいて，水分処置後ペンレス ${ }^{\circledR} 30$ 分間貼付したと きの痛みの程度をアンケート調査により評価し検証 した，その結果，透析患者においても，豚耳皮膚を 用いた基礎的検討と同様に水分処置により capacitance が上昇することが示されたものの，水

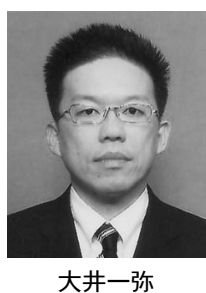

城西大学薬学部薬物治療管理学講座准 教授 薬剂師・薬学博士・Infection Control Doctor 四日市社会保険病院薬 剤部において臨床経験を有する（担当 患者数：1003 人). 研究領域：緩和久 ア領域での皮膚診断貼付法の確立, 救 急医学領域; 特に挫滅症候群における 治療法の確立, 腫瘍薬学領域 ; 抗がん 剂投与後の副作用軽減など. 
分処置後 30 分間貼付より従来の長時間貼付の方が 痛くないという傾向がみられた。しかし，患者の半 数は, 従来の方法と比べて痛夕が変わらない又は痛 くないと回答した。また，水分処置時の方が痛いと 回答した患者では，水分処置時の痛みのスコアが急 激に上昇するという傾向にあった．今回調査を行っ た透析患者の平均透析年数は 6.8 年であり, 従来か ら行われている貼付方法が患者に定着しているた め，貼付方法が変わることに対し心理的に抵抗感が あり，それが痛みのスコアに影響している可能性が 考えられた。

今回行った水分処置後にペンレスを貼付する方 法は，貼付時間短縮による副作用発現の軽減にもつ ながることが考えられ，また簡便に行えることか ら，透析患者におけるペンレス の効果的な貼付方 法として期待できることが示唆された.

\section{6. おわりに}

今回行ったペンレス ${ }^{\circledR}$ 最適な貼付条件の探索に 関する研究は，病院との共同体制で行った。つま り, 臨床現場での問題に対して, 大学が研究起案を 作成し病院と連携して臨床研究を実施し，そこで得 られたデー夕を臨床にフィードバックするというも
のである.ここで重要なことは，患者から発生した 問題点は，かならず患者に復するようにファーマシ ユーティカルケアを行うということである。そし て，高い臨床センスを磨くことが真の医療薬学を構 築することにつながると考える。

\section{REFERENCES}

1) Imamura Y., Matsuda K., Saijo K., Ishikawa M., Miyanari M., Tanaka A., Okabe C., Matsuzaki I., Ueda J., Onodera K., Hase H., Rinsho Toseki, 12, 1819-1823 (1996).

2) Ostlere L.S., Taylor C., Baillod R., Wright S., Nephrol. Dial. Transplant., 9, 1302-1304 (1994).

3) Szepietowski J. C., Sikora M., Kusztal M., Salomon J., Magott M., Szepietowski T., $J$. Dermatol., 29, 621-627 (2002) .

4) Park T.-H., Park C.-H., Ha S.-K., Lee S.-H., Song K.-S., Lee H.-Y., Han D.-S., Nephrol. Dial.Transplant., 10, 2269-2273 (1995) .

5) Zhai H., Ebel J. P., Chatterjee R., Stone K. J., Gartstein V., Juhlin K. D., Pelosi A., Maibach H. I., Skin Res. Technol., 8, 13-18 (2002). 